\title{
Tracking the evolution of dairy innovation system in Kerala
}

\author{
Sreeram Vishnu, Jancy Gupta and Shyam Suraj SR
}

Received: 24 October 2018 / Accepted: 01 January 2019 / Published online: 21 February 2019

(c) Indian Dairy Association (India) 2019

\begin{abstract}
This study is an attempt to explore the dairy sector of Kerala from an innovation system perspective. The objective is to analyze and study the dynamics of change catalyzed by the interaction of various actors, institutional mechanism and policy setting. Four unique stages are identified in the evolution of a dairy innovation system. The results suggest that the innovation system of this sector is growing, though its performance is yet to reach impressive levels. More actor engagement, institutional restructuring and policy orientation to address the emerging challenges are demanded to stimulate its performance and competitiveness. The study will be useful for policy makers to track the evolution of dairy innovation system in the State and to understand the factors influencing its dynamics.
\end{abstract}

Keywords: Actor dynamics, Dairying, Innovation system, Value chain

\section{Introduction}

An attempt is made to sketch the progress of dairy innovation system (DIS) in Kerala. Organized attempts to develop animal husbandry started with the launch of Key Village Scheme during

Sreeram Vishnu $(\bowtie)$

Agricultural Officer, Department of Agriculture and Farmers Welfare, Kerala, Pin: 679523, India

E-mail:srieeram@gmail.com

Jancy Gupta and Shyam Suraj SR

Division of Dairy Extension, ICAR-NDRI, Karnal, Haryana, Pin

132001, India 1950s in the state (Nair,1979). Later on, many of the development departments like Animal Husbandry Department, Cooperative Department, and Dairy Development Department etc. were organized; which catalyzed the technological revolution in dairy sector. Subsequently, the sector witnessed drastic changes during the Operation Flood - II (OF), both in the technological and institutional fronts. Proliferation of the cooperative network of dairy societies started thereafter, making the dairy production and marketing more organized. Though the state focused more on production oriented programmes after independence, it was later shifted to organizing marketing network and ensuring farmer's welfare. However, with the rapid decline in the cattle population coupled with a set of challenges including feed shortage, the growth of the sector is stagnant since early 2000. Among the milk producing states in the country; Kerala ranks $14^{\text {th }}$ with a meager share of 1.5 per cent of the total milk production in the country (Economic Review, 2017). Hence there is a renewed focus on productivity enhancement and self-sufficiency in milk production. The objective of this study is to explore the dynamics of events that happened in the dairy sector through an innovation system perspective which influenced the performance of the sector. An attempt has been made to identify and map the multitude of organizations, institutional mechanisms and policy changes which catalyzed the growth and progress of dairy innovation system in the State.

\section{Materials and methods}

The study was conducted as an attempt to understand the evolution of dairy innovation system in Kerala by looking into the milestone events, institutional and policy changes and emergence of relevant organizations. Extensive consultation with the key stakeholders like officials of veterinary and dairy departments, private dairy firms, traditional dairy cooperatives, KCMMF, experts of veterinary university and farmers were held to gather information relevant to this study. This is supplemented with information collected by reviewing annual reports of Dairy Development Department, Directorate of Animal Husbandry, Kerala Livestock Development Board, Kerala Cooperative Milk Marketing Federation and Livestock Census reports. Besides some of the important documents like Agricultural Development Policy (2015)of the State, Farm Guide (2016), study reports of 
NDDB (2017),Kerala State Council for Science, Technology and Environment (2018), expert committee reports (2009) were also reviewed for the purpose of this study. Though study reports were available with respect to dairying in Kerala, we could hardly find a report consolidating various landmarks and happenings of dairying in the State. Data were collected during the period July 2016 to March 2017.

\section{Results and discussion}

\section{The evolution of dairy innovation system in Kerala}

The dairy innovation system in the state is shaped over the years, with the engagement of multifarious actors ranging from the public, private, cooperative and independent domains, organized around the dominant small holder producers. Distinct stages can be identified which mark milestones in the history of dairying in Kerala. Four major stages were identified with respect to the emergence and growth of DIS in the State which are discussed below.

\section{Period of conception (Before 1947)}

Travancore, a prominent princely state of Kerala during the British period had a veterinary hospital as early as in 1905. In 1908, when agriculture department was formed in the State, veterinary and fisheries establishments of Travancore were brought under the same. However under the British imperialist regime, livestock sector was never accorded due recognition and was treated as a native affair to be looked after by the provincial governments (Anonymous, 2009). The first attempt to conceive a set of policies for livestock development in India was initiated by the Royal Commission on Agriculture in 1928. In its report, the Commission discoursed in detail on animal husbandry as an enterprise and its viability in the Indian context. It was the Madras Government, which gave shape to a separate veterinary department in 1936 delinking it from agriculture. In 1939 by starting the Calicut milk union, efforts to organize milk cooperative societies got initiated. However, the first dairy co-operative in Kerala, the Palakkad Cooperative Milk Supply Union Ltd, was registered in 1949 (Sasikumar, 2009).

\section{Period of structural growth (1947-1980)}

During this phase, all the prominent organizations responsible for spearheading the innovation management in the dairy sector were established. It began with the Key Village Scheme (KVS), the first organized effort for the development of the livestock sector after independence. It gave emphasis on increasing the supply of breeding bulls by setting up bull breeding farms in the major cattle growing tracts (George and Nair, 1990). Though the state had veterinary hospitals at the time of its official formation and had veterinary department during the British colonial period itself, it was only in 1956 an exclusive department, the Department of Animal Husbandry (DoAH) was established (Anonymous,
2009). The department was mandated with delivery of technical services, animal health care, disease prevention and eradication, training and extension activities etc. Subsequently, the Dairy Development Department (DDD), was established in 1962, to take a lead role in carrying out dairy extension activities, promotion of cross breeding, fodder development as well as milk procurement and marketing in the State. Later, in 1963 establishment of IndoSwiss projectbecame a landmark in the history of dairying in Kerala. The project played a catalytic role in the genetic improvement of dairy animals. Frozen semen technology for Artificial Insemination (AI) was introduced for the first time in Asia through this project. As a part of the project, Mattuppetty farm, one of the pioneer centers of animal production and breeding research in India was established. Cattle Improvement Assistants (CIAs) under DDD played an initial lead role in spreading AI to remote villages. The project later played a pivotal role in establishing considerable livestock infrastructure like AI centers in collaboration with DoAH and Integrated Cattle Development Project (ICDP) (Anonymous, 2013). The ICDP played a key role in improving the quality and productivity of cattle in the State. The project aimed to cover maximum breedable cows and other aspects of dairy development such as breeding, balanced feeding practices and effective disease control. AI services were offered at farmer's doorstep with the deployment of CIAs on a massive scale (Sasikumar, 2009). The first private dairy development project of the State, People's Dairy Development Project (PDDP) was started only in 1973. It was an extension of Ernakulam Welfare Services, an organization responsible for the promotion of welfare activities in the Archdiocese of Ernakulam. The project actively promoted dairying as a potent tool in its efforts to eradicate poverty and to secure livelihood of the marginalized farmers in the lines of cooperative action and mobilization. Further in 1976, Kerala Livestock and Milk Marketing Board (KLD\& MMB) was established by amalgamating Indo- Swiss Project, Mattuppetty and the Bull Station at Dhoni, Palakkad managed by DDD. It was a registered company fully owned by the State Government, mandated with designing and implementing planned breeding programmes as well as promotion of technological innovations, training activities, fodder promotion and milk marketing (Kerala Livestock Development Board, 2016).

The national dairying scenario witnessed an overhaul during this period with the implementation of Operation Flood (OF) under the aegis of National Dairy Development Board (NDDB). The basic rationale of $\mathrm{OF}$ was linking of rural milk producing centres with the urban demand centres, to build up a viable dairy industry (KCMMF, 2016). However, the State was not part of the first phase of OF started in 1970s and joined only later in its second phase initiated in 1980s. Kerala Cooperative Milk Marketing Federation (KCMMF) was registered to implement the project in the State (KCMMF, 2016). It came into existence to take up milk procurement and marketing activities previously done by KLD \& MMB (renamed as Kerala Livestock Development Board KLDB). It had a three tier co-operative framework with Primary 
Table 1 Landmark events in the history of dairying in Kerala

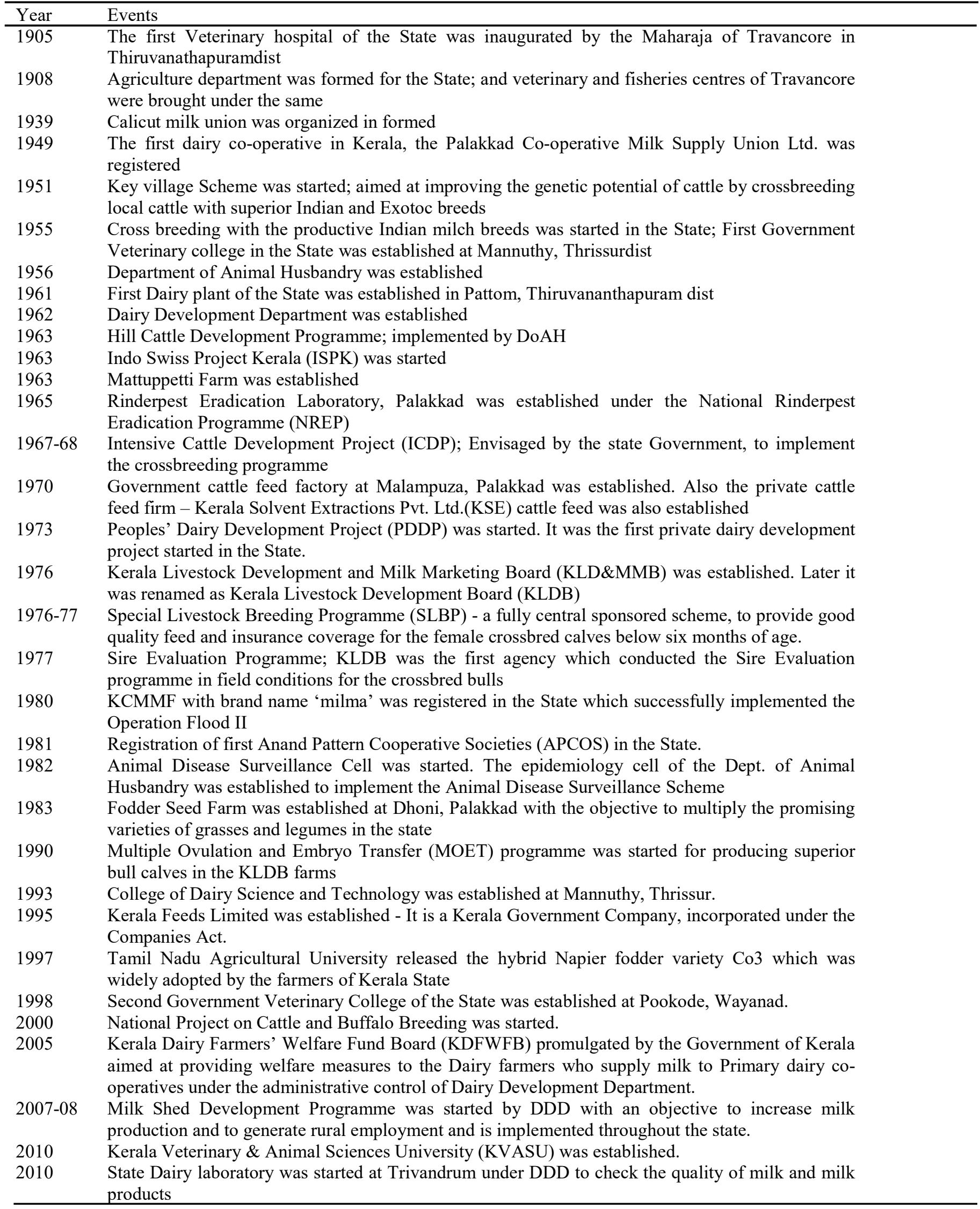


Figure 1 Causal Loop diagram - Emergence of the dairy innovation system

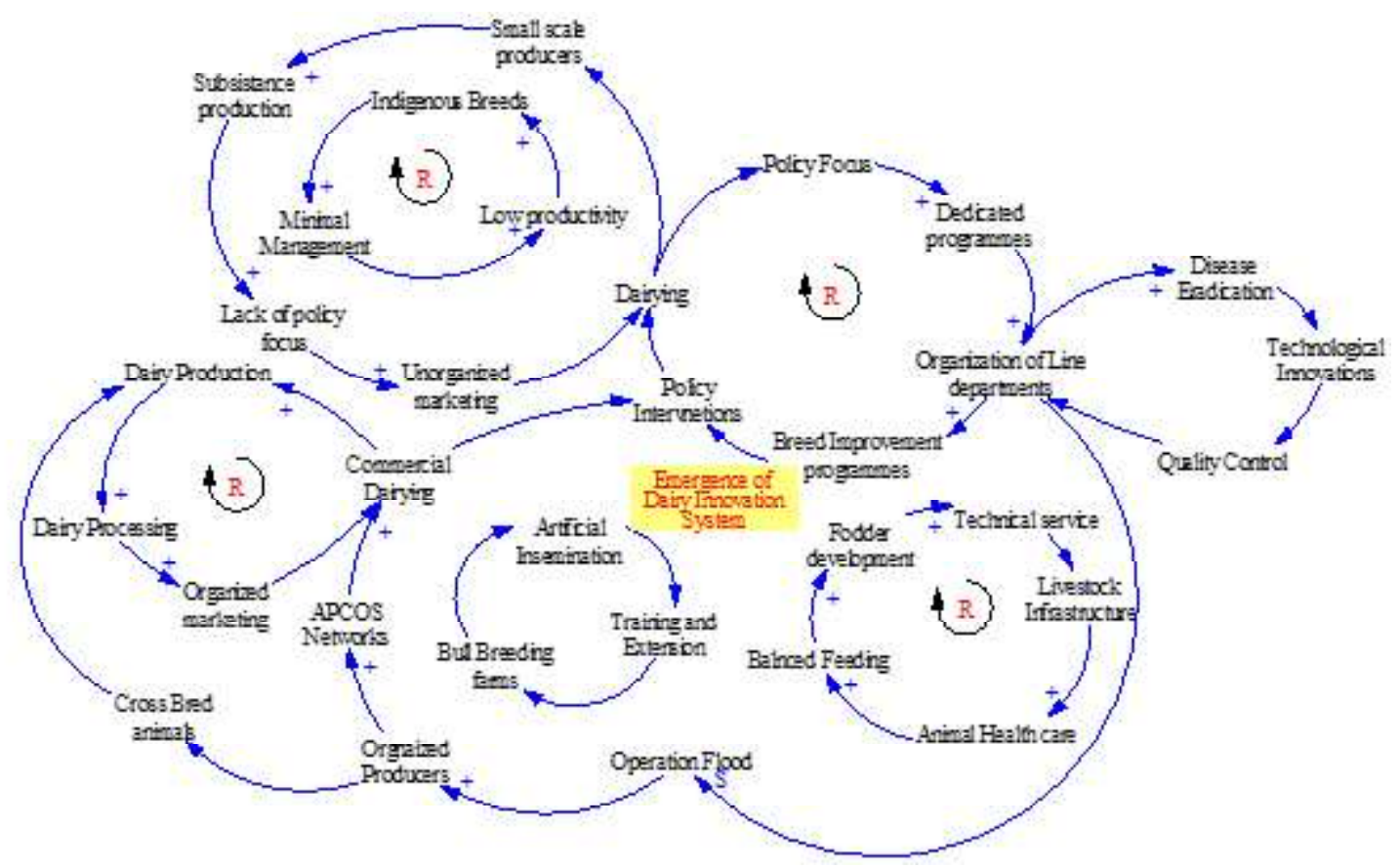

Figure 2 Causal Loop diagram: Growth of the dairy innovation system

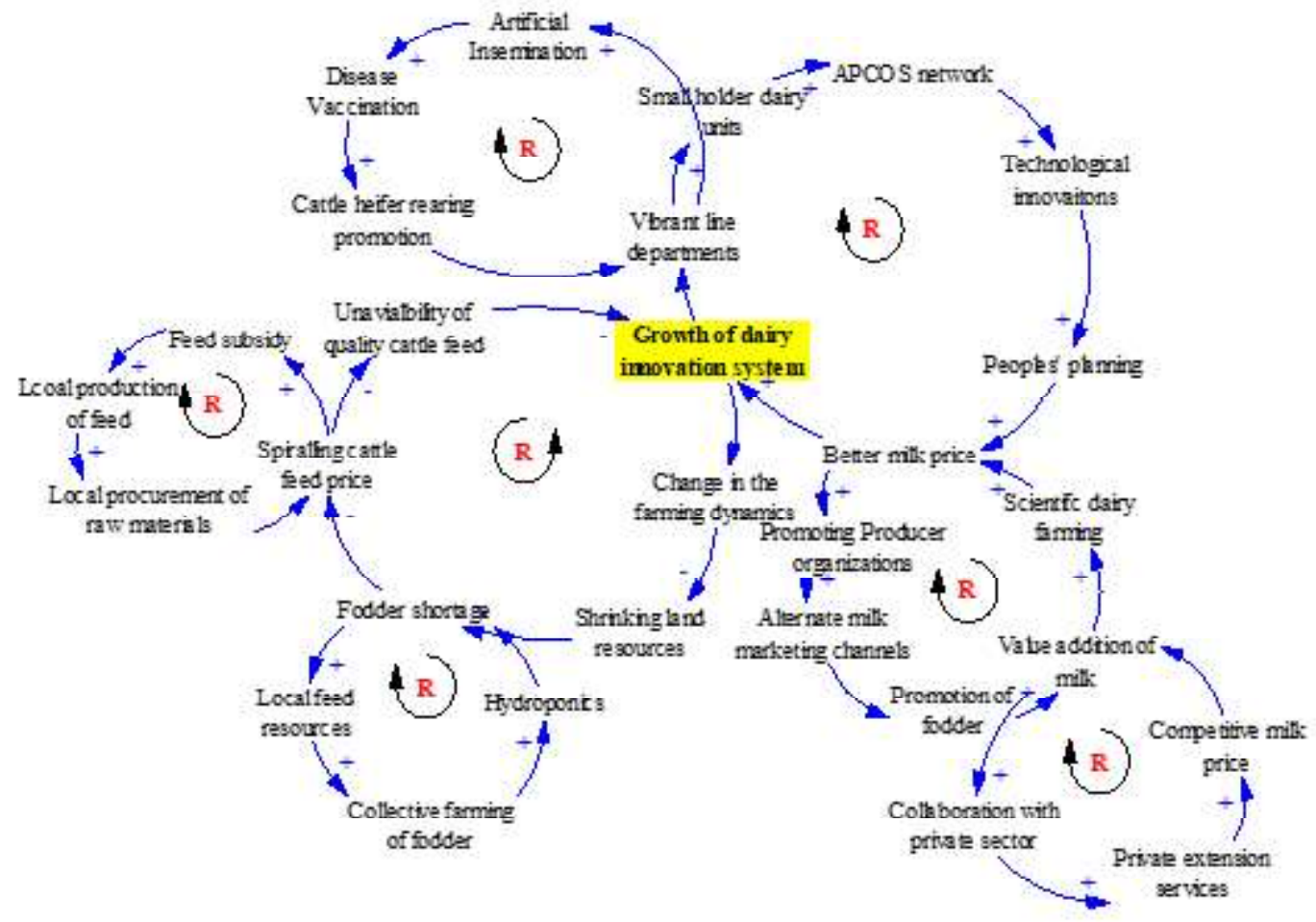

milk producer societies at the village level, Regional producers' union at the middle level and the Federation at the apex level of programme catalyzed the spread of Anand pattern cooperative societies (APCOS) network throughout the State. With the formation of KCMMF, all the dairy units and assets under the DDD were handed over to the new organization. KCMMF was assigned with coordinating the procurement, processing and marketing of milk and milk products as well as organizing the milk producers under the cooperative fold. Phase III (1985-1996) of enabled dairy co-operatives to expand and strengthen the infrastructure required to procure and market increased volumes of milk (Rajendran and Mohanty, 2004). In 1981, the first Anand Pattern Co-operative Society (APCOS) was registered and such societies continued to multiply at a faster pace in all parts of 
Kerala. In order to track the evolution of the dairy innovation system with the various driving $(+)$ and restraining (-) forces, causal loop diagrams were drawn. The Figure 1 below depicts key factors contributed to its emergence. Various landmark events in the history of growth and establishment of dairy innovation system in the state were identified and is presented in the following table (Table 1).

\section{Period of progression (1980-2008)}

The entire state was brought under APCOS network by early 1990s with the implementation of North Kerala Dairy Project (NDKP) supported by Swiss Development Agency to establish Malabar Regional Union of KCMMF. The new economic policy unveiled by the Government during 1991 at the national level had widespread repercussions in the dairy sector. The sector was de-licensed and was opened up for the private entrepreneurs including multi-nationals. The rationale was to encourage competition in procurement and marketing of milk and thereby enhance value for both producers and consumers. As a result, the private sector, a silent participant of the national dairy innovation system till then, started venturing into the sector vigorously throughout the country and offered a strong competition to the cooperative set up. During this phase, a lot of programmes were launched to rejuvenate the sector. Clean Milk Production Programme in 1991 to improve the quality of milk, appointment of Women Cattle Care Promoters in 1993 to develop a special category of women extension agents with expertise in dairying by co-operatives were some of the notable initiatives (Sasikumar, 2009).

In the year 2000, a centrally sponsored programme, National Project on Cattle and Buffalo Breeding (NPCBB) was implemented under the aegis of KLDB. It was aimed to cover the entire breedable cattle of the State through AI programme using frozen semen. Towards the end of the century, India became largest milk producer in the world, from the status of a net importer of milk in 1960s. Dairy production in Kerala got immensely benefited from the genetic up-gradation programmes undertaken by the state, resulting in cattle population with above 80 percent cross breeds (Dairy Development Department, 2014).Along with that, the demand for cattle feed and fodder also rose to higher proportions. The demand for cattle feed was mainly supplied by the organized cooperative sector, private sector and small units (Francis, 2003). Figure 2 portrays the growth of the dairy innovation system in Kerala.

\section{Period of consolidation (From 2008 onwards)}

Several remarkable changes happened to the dairy innovation landscape of the State during this period. The State formulated an exclusive breeding policy for it in 2008, following the sluggish growth of the sector. The policy outlined many unique measures to regain the growth in milk production like specification of donor breeds and limiting the level of exotic inheritance to 50 percent. Besides it propounded the need to incorporate embryo transfer (ET) technology in the production of breeding bulls and the need to introduce mobile AI programme in all the centres. In 2010, an exclusive university, Kerala Veterinary and Animal Sciences University (KVASU) dedicated for the livestock sector was established in the State. Presently there are four dairy technology colleges, two veterinary colleges, one food technology college, one avian science college, 17 research stations/units and two veterinary hospitals functioning under KVASU. Also an exclusive directorate for promoting entrepreneurship in the livestock sector was established under the university, which promotes innovation through experimentation and enterprise building. This centre coordinates the technology business incubation and has its focus on research, extension and outreach activities (KVASU, 2015).A dedicated organization, Kerala Dairy Farmers' Welfare Fund Board (KDFWFB) was formed by Government of Kerala in 2005, to provide welfare measures to dairy farmers who supplied milk to dairy co-operatives under the administrative control of Dairy Development Department (Suraj and Hari, 2015). Number of dairy development projects were initiated by DoAH, DDD and SC/ST Departments to improve the fodder resources as well as health and productivity of livestock. The state government too had its renewed focus on dairying, with the increased financial allocation for the sector in 2012 (Anonymous, 2013). Besides, there were some initiatives by the central and state governments to rejuvenate the sector. These programmes had diverse focus, like

Table 2 Key dairying parameters of Kerala

\begin{tabular}{|c|c|c|c|c|}
\hline \multirow{2}{*}{$\begin{array}{l}\text { Sectorial } \\
\text { parameters }\end{array}$} & \multicolumn{2}{|l|}{ Cattle Population(2017) } & \multirow{2}{*}{$\begin{array}{l}\text { Milk Production } \\
(2016-17) \text { in Lakh Tonnes }\end{array}$} & \multirow{2}{*}{$\begin{array}{l}\text { Meat Production } \\
(2016-17) \text { in MT }\end{array}$} \\
\hline & Indigenous(lakh) & Cross bred(lakh) & & \\
\hline & 0.77 & 12.51 & 2520 & 4.69 \\
\hline $\begin{array}{l}\text { Institutional } \\
\text { parameters }\end{array}$ & $\begin{array}{l}\text { Number of veterinary } \\
\text { hospitals/Dispensary }\end{array}$ & & Number of AI centers & $\begin{array}{l}\text { Dairy Cooperative } \\
\text { societies }\end{array}$ \\
\hline & 1069 & & 2515 & 3648 \\
\hline $\begin{array}{l}\text { Service related } \\
\text { parameters }\end{array}$ & $\begin{array}{l}\text { Frozen semen } \\
\text { production (lakh doses) }\end{array}$ & & $\begin{array}{l}\text { Number of AIs } \\
\text { performed (lakh) }\end{array}$ & $\begin{array}{l}\text { Area under fodder } \\
\text { cultivation }(\mathrm{Ha})\end{array}$ \\
\hline
\end{tabular}

Sources: NDDB (2017); Economic Survey (2017); Directorate of Animal Husbandry (2018); Dairy Development Department (2017) 
enhancing the marketing network, boosting milk production and rural employment, insurance coverage for animals and farmers, entrepreneurship development etc. They include the Samagra Project in 2008, Milk Shed Development Programme (MSDP) in 2007, Dairy Entrepreneurship Development Scheme (DEDS) in 2010, Gosuraksha Scheme in 2011 and Mini Dairy Units under RashtriyaKrishiVikasYoajana (RKVY) in 2010 (Dairy Development Department, 2017).

\section{The present Status of DIS}

The dairy innovation system is growing slowly but steadily over the last few years.KCMMF is the dominant player in the milk marketing and at the grass root level; it has 3206 APCOS registered under DDD with 9.24 lakh milk producing farmers as members (KCMMF, 2016).It handles 80 percent of milk under the organized sector. By and large, it contributes to the progress of dairying in multiple ways like assuring a market for milk at a stable price, logistical support like transportation, storage facilities and prompt payment to producers (Ashwin, Undated).Further, KCMMF offers various support services like supply of mineral inputs, cattle feed, medical aid and AI services to the farmers. During 2016-17, a total of 5940 lakh litres of milk was procured by the dairy co-operative societies in the State and the average milk procured per day by APCOS was 1082 MT (Economic Review, 2017).In addition there are 457 dairy cooperatives which are functioning in the traditional mode (Dairy Development Department,2017). Thus, today the state has a well-organized milk procurement and marketing network. Table 2, shows the key dairying parameters of the State.

However, rapid decline in the population of animals in general and indigenous non-descript animals in particular, pose a serious threat to the dairy production. All types of livestock have been showing a declining trend in Kerala after 1996 (ENVIS, 2018). As per the 2012 Livestock Census, there are 13, 28, 000 cattle in Kerala; showing a sharp decline of 24 per cent from the 2007 census. Various survey reports indicate that low productive local animals are replaced with good potential cross breeds at a faster pace. On the other hand, projection studies indicate that milk demand would escalate to 35.19 lakh tonnes by 2030 from the base year (2009-10) level of 27.94 lakh tonnes. Though presently the State manages to meet 70 per cent of its milk requirement through domestic production, the current growth rate is quite inadequate to bridge the demand gap (Anonymous, 2013, Dairy Development Department, 2014). Inadequate feed and fodder, low productivity of the cross breed animals and limited availability of health services and poor dairy management practices among the farmers are the reported problems of the dairy sector in Kerala (Joseph, 2014).

Further, animal husbandry is not granted an equal consideration with agriculture in terms of subsidies and other services from the governmental and banking institutions. Hence these constraints can be seen as the limiting factors, which contain the growth of the DIS in the State. Some of the challenges already got the attention of the policy makers, like to meet the growing fodder requirement of the cattle. The declared plan of DDD to observe "Fodder Promotion Year" started by 2016 to promote fodder cultivation, reiterates this argument (Dairy Development Department, 2017).Various policy documents including the Tenth Plan strategy document, Kerala Perspective plan 2030 and Agricultural Development Policy (2015) underscores a number of measures to build the competitiveness of the sector. These include, upgrading the standards of veterinary institutions and services, establishment of disease free zones, promoting farming system approach, increasing the production through scientific management and enhancing the fodder base and availability.

\section{Conclusions}

The study made an attempt to track the growth and evolution of dairy innovation system in the State. The analysis suggest that public sector actors still holds the key in determining the dairy production whereas the role of cooperative sector is evident in the post production and marketing. Private sector firms are still playing a marginal role, which are mainly involved only in input and service provisions. Hence there is more scope for private sector engagement especially at the post production stage. Further the set of challenges need to be addressed through specific policy measures keeping the dominant small and marginal producers, who possess the largest share of cattle wealth. Immediate action is required to check the fast declining cattle wealth by supporting small holder dairying and projecting dairying as a profitable enterprise. Moreover, the competitiveness of the sector has to be built through specific interventions like provision of incentives, institutional support and assured returns. More interventions are demanded at the dairy value chain to harness the full potential of the sector and to stimulate the growth of DIS

\section{Acknowledgements}

The authors thankfully acknowledge officials of line departments related to dairying and veterinary as well as KCMMF for providing valuable information for this study.

\section{Conflict of interest: None}

\section{References}

Agriculture Development Policy(2015) Government of Kerala.Retrieved from https://kerala.gov.in/documents/10180/46696/ AGRICULTURAL\%20DEVELOPMENT\%20POLICY\%202015

Anonymous (2009) Status paper. Expert Committee to Submit Recommendations to Attain Self-Sufficiency in the Production of Milk, Meat and Egg. Retrieved from http://vetconcerns.org/wpcontent/ uploads/ 2015/06/Milk-Meat-Eggs-Enhancement-R-HaliCommittee-report1.pdf 
Anonymous (2013) Kerala Perspective Plan. Kerala State Planning Board.

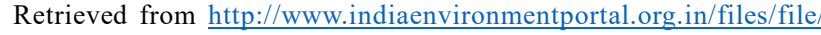
Kerala\%20Perspective\%20Plan\%202030.pdf

Ashwin (Undated)Overview of dairy industry. Retrieved from http:// shodhganga. 08 chapter1.pdf

Dairy Development Department (2017) Number statement -Dairy cooperatives.Retrieved from http://www.dairy.kerala.gov.in/ index.php/statistics/societies/society-details

Dairy Development Department (2014) Administrative report 2013-14. Retrieved from http://www.dairy.kerala.gov.in/images/PDF/Circulars/ admin1213.pdf

Dairy Development Department(2017) State Schemes. Retrieved from http://www.dairy.kerala.gov.in/index.php/schems/state-schemes

Directorate of Animal Husbandry (2018) Statistics. Retrieved from https:/ /ahd.kerala.gov.in/

Economic Review (2017) Livestock. State Planning Board, Thiruvananthapuram, Kerala, India.Retrieved from http:// spb.kerala.gov.in/ER2017/web_e/ch24.php?id=2\&ch=24

ENVIS Centre (2018) Livestock.Kerala State Council for Science, Technology and Environment. Retrieved from http:// www.kerenvis.nic.in/Database/Livestock 2271.aspx

Farm Guide(2016) Farm Information Bureau. Retrieved from https://

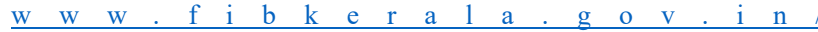
index.php?option $=$ com $\_$content\&task $=$view $\& i d=354 \&$ Itemid $=124$

Francis P (2003) Problems and prospects of cattle feed manufacturing units in Kerala. MSc.Thesis. Department of Commerce and Management Studies, University of Calicut, Kerala.

George PS, Nair KN (1990) Livestock Economy of Kerala, Centre for Development Studies, Trivendram, Kerala

Joseph MK (2014) Village Milk Cooperatives in Kerala. PhD Thesis submitted to Mahatma Gandhi University.Retrieved fromhttp:// hdl.handle.net/10603/25826
Kerala Cooperative Milk Marketing Federation (KCMMF) (2016) Annual Report, 2015-16. Retrieved from http://kcmmf.in/images/tender/ MILMA Annual Report 2015-16.pdf

Kerala Livestock Development Board(KLDB) (n.d) Livestock Scenario. Retrieved from http://www.livestock.kerala.gov.in/ index.php\%3Foption $=$ com_content $\&$ view $=$ article $\&$ id $=48 \&$ Itemid $=55 . \mathrm{html}$

Kerala Livestock Development Board (KLDB) (2016) Livestock Scenario. Retrieved from http://www.livestock.kerala.gov.in/ index.php $\% 3$ Foption=com content\&view $=$ article $\&$ id $=48 \&$ Itemid $=55 . \mathrm{html}$

Kerala Veterinary and Animal Sciences University (KVASU)(2015)Entrepreneurship @ Kerala Veterinary and Anima Sciences University. Retrieved from http://www.kvasu.ac.in/ directorate-of-entrepreneurship-1

Nair KN (1979) Milk production in Kerala: Trends and prospects. Economic and Political Weekly A25-A39

National Dairy Development Board (NDDB)(2017) Dairying in Kerala- A statistical profile. Retrieved from http://dairyknowledge.in/sites/ default/files/nddb-kerala 11-4-16.pdf

PDDP (2000) Peoples Dairy Development Project, Kalady: A brief sketch. PDDP Central Society, Kalady.

Rajendran K, Mohanty S (2004) Dairy co-operatives and milk marketing in India: Constraints and opportunities. Journal of Food Distribution Research 35 (2): 24-41

Sasikumar S (2009) A Brief Study on Dairy Industry in India. Institute of Cooperative Management, University of Kerala, Thiruvanthapuram. Retrieved fromhttp://icmimk.blogspot.in/2009/07/brief-study-ondiary-industry-in-india.html

Suraj S, Hari R (2015) Kerala Dairy farmers' Welfare Fund Board: An experiment worth emulation from Kerala. Indian Dairyman 60(3): $65-68$ 